\title{
Erratum to: Lessening the adverse effect of the semivariogram model selection on an interpolative survey using kriging technique
}

Zakari Arétouyap ${ }^{*}$, Philippe Njandjock Nouck', Robert Nouayou' ${ }^{1}$, Franck Eithel Ghomsi Kemgang ${ }^{1}$, Axel Dorian Piépi Toko ${ }^{1}$ and Jamal Asfahani²

\section{Erratum to: SpringerPlus (2016) 5:549 DOI 10.1186/s40064-016-2142-4}

In the publication of this article (Arétouyap et al. 2016), there was an error in the Competing Interests section. The error: 'Prof. Asfahani is the Head of Atomic Energy Commission of Syria' should instead read: 'Prof. Asfahani is the Head of the Applied Geophysics Division at the Atomic Energy Commission of Syria.'

\section{Author details}

${ }^{1}$ Postgraduate School of Science, Technology and Geosciences, University of Yaounde I, P.O. Box 812, Yaounde, Cameroon. ${ }^{2}$ Applied Geophysics Division, Head Atomic Energy Commission, P.O. Box 6091, Damascus, Syria.

The online version of the original article can be found under doi:10.1186/s40064-016-2142-4.

Received: 27 May 2016 Accepted: 27 May 2016

Published online: 04 July 2016

\section{Reference}

Arétouyap Z, Njandjock Nouck P, Nouayou R, Ghomsi Kemgang FE, Piépo Toko AD, Asfahani I (2016) Lessening the adverse effect of the semivariogram model selection on an interpolative survey using kriging technique. SpringerPlus 5:549

\footnotetext{
*Correspondence: aretouyap@gmail.com

1 Postgraduate School of Science, Technology and Geosciences, University of Yaounde I, P.O. Box 812, Yaounde, Cameroon

Full list of author information is available at the end of the article
} provided you give appropriate credit to the original author(s) and the source, provide a link to the Creative Commons license, and indicate if changes were made. 